\title{
Capillary refill time in febrile neutropenia
}

\author{
Adriana Gherardi da Ponte ${ }^{1 *}$, Rafael Henrique Jácomo ${ }^{2}$ \\ ${ }^{1} \mathrm{MSc}$ in Medicine from Universidade de Brasilia (UnB), Brasilia, DF, Brazil \\ ${ }^{2}$ PhD in Hematology from Universidade Federal de São Paulo (Unifesp), São Paulo, SP, Brazil
}

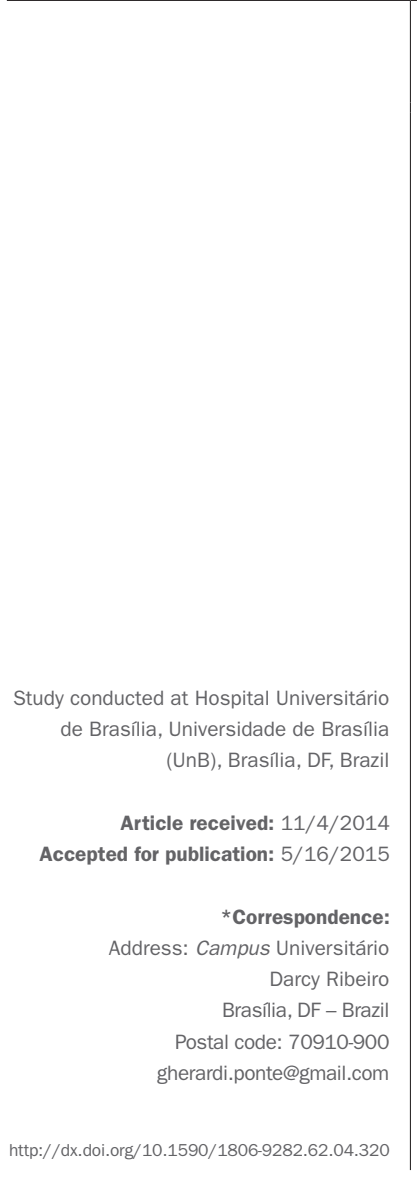

\section{SUMMARY}

Introduction: Febrile neutropenia is a major cause of morbidity and mortality in patients presenting this condition following chemotherapy against several malignancies.

Objective: To evaluate if capillary refill time (CRT) allows the prediction of poor clinical outcome with or without antibiotic dose escalation.

Method: Capillary refill time was assessed in 50 patients with febrile neutropenia at its nadir after chemotherapy admitted to the emergency department at Hospital Universitário de Brasília. All patients included had a minimum average arterial blood pressure of $75 \mathrm{mmHg}, \mathrm{O}_{2} / \mathrm{FiO}_{2}$ saturation rate > 300, and 15 points in the Glasgow coma scale. Inclusion depended on at least three of the systemic inflammatory response syndrome (SIRS) criteria, suspected infection, and neutropenia after chemotherapy. Capillary refill time was calculated by pressing the index finger for 15 seconds, and then timing the return to the initial color. We studied whether there is a relationship between CRT and antibiotic escalation. The gold standard used to gravity was the level of lactate.

Results: 31 patients had CRT $\geq 3$ seconds, which it is associated with increased serum concentration of lactate ( $>2 \mathrm{mmol} / \mathrm{L} ; \mathrm{p}<0.05)$. 32 patients underwent antibiotic escalation, which it is associated with CRT $\geq 3$ seconds $(\mathrm{p}<0.01)$.

Conclusion: CRT higher than three seconds was effective to predict antibiotic escalation.

Keywords: neutropenia, body temperature changes, perfusion, fever.

\section{INTRODUCTION}

Febrile neutropenia is a common and potentially fatal complication in patients undergoing chemotherapy for various cancers and is considered a medical emergency. ${ }^{1}$ It is defined by the presence of neutropenia associated with fever or hypothermia. Neutropenia, in a complete blood count, is a neutrophil count of less than 500/ $\mathrm{mm}^{3}$ or between 500 and $1000 / \mathrm{mm}^{3}$ if there is a downward trend. Fever is a state in which oral temperature is equal to or greater than $38.3^{\circ}$, or axillary temperature is equal to or greater than $37.8^{\circ}$, or even persistence of temperature between 38 and $38.3^{\circ}$ for over an hour. Hypothermia is defined as axillary temperature lower than $35.5^{\circ} .2$

Capillary refill time has been used for decades in medicine to assess peripheral perfusion. ${ }^{3}$ In 1980 , this measure was introduced as severity score in trauma. ${ }^{4,5}$ Its reliability is much questioned. However, a comparative study between transcutaneous partial pressure of $\mathrm{O}_{2}$ and capillary refill time demonstrated its effectiveness to assess peripheral perfusion. ${ }^{6}$

Since the advent of chemotherapy, at the end of the 1950s, the prognosis of patients with cancer has improved, but the appearance of chemotherapy-induced neutropenia and its relation to the risk of infection became clear. ${ }^{1}$ Neutropenia is the most common complications of chemotherapy; 25 to $50 \%$ of patients in the post-chemotherapy period develop febrile neutropenia, reaching $80 \%$ in hematological tumors.

The complications of febrile neutropenia are severe sepsis and progression to multiple organ failure with a high mortality rate. 
Often, the only symptom is fever, which is a major challenge.

Treatment should be initiated as early as possible. If the blood count takes longer than 30 minutes, the recommendation is to start broad-spectrum antibiotics immediately.

Central venous oxygen saturation was compared to different capillary refill times, leading to the observation that central venous oxygen saturation equal to or greater than $70 \%$ is associated with a CRT $<2$ seconds, showing the reliability of the latter.

The main question has always been validation and its applicability validated in adults. In 2009, the CRT was validated compared to blood lactate levels. ${ }^{8}$

CRT and skin temperature, together, are good predictors of peripheral perfusion. Their importance is clear in the patient's admission to the emergency department. The temperature gradient can better reflect the patient status compared to the skin temperature alone.,8

In a setting of constant temperature, the central-toperipheral gradient rises and the peripheral-to-ambient gradient declines when there is vasoconstriction. Ambient-to-skin temperature gradient can reveal changes in blood flow in the skin. Increased blood flow leads to heat being transferred from within the body toward the skin. Decreased blood flow also decreases heat conduction from core tissues to the periphery. During vasoconstriction skin temperature falls, heat transfer within the body drops, and the gradient increases. A gradient of $3-7^{\circ}$ from core tissues to the periphery indicates a stable hemodynamic status. Ambient temperature $<20^{\circ}$ undermines the use of this gradient. Temperature changes in the environment affect the temperature as a whole, having little influence on the gradient. Experimental studies have suggested a gradient limit of $4^{\circ}$ for severe vasoconstriction. ${ }^{9}$

\section{Objective}

To assess whether the capillary refill time can predict poor clinical outcome in patients with febrile neutropenia after chemotherapy. The clinical outcome was antibiotic escalation.

\section{Method}

Capillary refill was timed in patients with post-chemotherapy febrile neutropenia admitted to the emergency department of Hospital Universitário de Brasília. We assessed if a longer capillary refill time (CRT) can predict severity in these patients through monitoring of their medical progress.
This is a prospective observational study. The total of patients was 50. There was no intervention. Inclusion criteria were patients complaining of fever and/or chills, or hypothermia after chemotherapy and systolic blood pressure greater than $90 \mathrm{mmHg}$. In such cases, the investigator was called to check the other inclusion criteria, namely: age greater than 18 years, nadir after chemotherapy, neutrophils less than $500 / \mathrm{mm}^{3}$ or between 500 and 1000 but with a downward trend. Also, mean arterial pressure $(\mathrm{MAP})>$ or equal to $75 \mathrm{mmHg}$, axillary temperature (Tax) $>38.3^{\circ}$ or Tax $<36^{\circ}$, heart rate $>90 \mathrm{bpm}$, respiratory rate $>20 \mathrm{bpm}$; thus, with systemic inflammatory response syndrome and suspected infection based on change in cough or new cough, or recent abdominal pain with or without diarrhea. Not being treated with metformin, not having a history of peripheral arterial disease, not being treated with leukocyte-activating factor, agreeing to take part in the study, not being treated with angiotensin-converting enzyme inhibitors, hemoglobin > or equal to $8 \mathrm{~g} / \mathrm{dL}$, Glasgow coma scale equal to $15, \mathrm{O}_{2} / \mathrm{FiO}_{2}$ saturation rate $>300$, and not using oxygen at home.

CRT was measured by pressing the distal phalanx of the right index finger of the patient for 15 seconds, with measurement of time using a stopwatch. CRT was considered prolonged when the time was equal to or greater than three seconds.

CRT was always measured in the same room and by the same person. Concomitantly, the temperature gradient between ear cavity and the ipsilateral hallux was measured, with $7^{\circ} \mathrm{C}$ being considered as peripheral vasoconstriction, i.e., redistribution of blood flow at an early stage.

The temperature was measured using infrared digital thermometer inserted into the external auditory meatus, followed by evaluation of the temperature gradient and CRT.

This study was approved by the Research Ethics Committee.

\section{Results}

In order to analyze the association of a CRT equal to or greater than three seconds with the temperature gradient between ear cavity and the ipsilateral hallux, Fisher's exact test was performed (Table 1). Of the 34 patients with CRT equal to or greater than three seconds, 31 had gradients equal to or greater than 7 degrees, while among those with CRT below 3 (16) only one presented a temperature gradient within this range $(\mathrm{p}<0.01)$. Measuring the temperature gradient together with CRT aimed to reduce the subjectivity of CRT research. 
TABLE 1 Temperature gradient vs. CRT.

\begin{tabular}{llll}
\multirow{2}{*}{ Ear-hallux temperature gradient } & \multicolumn{2}{c}{ CRT } & Total \\
\cline { 2 - 3 } & $\mathbf{2}$ & $\mathbf{2}$ & \\
\hline$\geq 7$ & 31 & 1 & 32 \\
\hline$<7$ & 3 & 15 & 18 \\
\hline Total & 34 & 16 & 50
\end{tabular}

Temperature gradient in ${ }^{\circ} \mathrm{C}$ between ear canal and ipsilateral hallux regarding; CRT: capillary refill time.

\section{Lactate}

In this variable, the amount of lactate in patients was observed. Capillary refill times equal to or greater than three seconds corresponded to lactate levels higher than 2.0 $\mathrm{mmol} / \mathrm{L}$.

To analyze if the CRT (whenever equal to or greater than 3 seconds) and lactate (greater than 2) variables are independent from each other, Fisher's exact test was performed (Table 2).

\section{TABLE 2 Lactate levels and CRT.}

\begin{tabular}{llll}
\multirow{2}{*}{ Lactate } & \multicolumn{2}{c}{ CRT } & Total \\
\cline { 2 - 3 } & $\mathbf{2}$ & $\boldsymbol{<}$ & \\
\hline$>2$ & 31 & 1 & 31 \\
\hline$\leq 2$ & 3 & 16 & 19 \\
\hline Total & 34 & 16 & 50 \\
\hline
\end{tabular}

Lactate in mmol/L; CRT: capillary refill time.

\section{CRT and lactate levels}

The obtained $\mathrm{p}$-value was $\mathrm{p}<0.05$; therefore, CRT greater than three is associated with increased serum concentration of lactate.

\section{CRT and antibiotic escalation}

The CRT analysis showed that patients with CRT greater than three seconds had a greater need for antibiotic escalation $(\mathrm{p}<0.01)$ (Table 3$)$.

TABLE 3 Antibiotic escalation and CRT.

\begin{tabular}{llll}
\multirow{2}{*}{ Antibiotic escalation } & \multicolumn{2}{l}{ CRT $\geq 3$} & \multirow{2}{*}{ Total } \\
\cline { 2 - 3 } & Yes & No & \\
\hline Yes & 32 & 1 & 33 \\
\hline No & 2 & 15 & 17 \\
\hline Total & 34 & 16 & 50 \\
\hline
\end{tabular}

Antibiotic dose escalation; CRT: capillary refill time, in seconds.

\section{Discussion}

The levels of lactate corresponded to the capillary refill time. Lactate is a predictor of severity that does not de- pend on the etiology of a clinical status, the cause of shock, or on inadequate tissue perfusion. CRT is, therefore, a predictor of severity. Lactate is considered the gold standard in this study. CRT, which was a predictor of severity in this group neutropenic febrile patients, is a practical and simple clinical sign, and could be incorporated in the evaluation of these cases. CRT was able to predict, together with the lactate level, a bad clinical outcome which is antibiotic escalation. Antibiotic dose escalation leads to longer length of hospital stay, which is considered very harmful to patients with impaired immunity due to low neutrophil count. CRT pointing to greater severity in a nonspecific manner implies that we do not know whether patients with CRT actually have an increased deficit volume or a greater chance of progressing to severe sepsis and multiple organ failure.

\section{Conclusion}

There was a statistical relationship between lactate and capillary refill time, and between the latter and antibiotic escalation. Therefore, in this group of patients, the CRT allowed the prediction of poor clinical outcome, since antibiotic escalation implies longer hospital stays and higher chance of complications.

\section{Resumo}

Tempo de enchimento capilar e neutropenia febril

Introdução: a neutropenia febril é uma das principais causas de morbimortalidade nos pacientes neutropênicos febris pós-quimioterapia para neoplasias diversas. Objetivo: avaliar se o tempo de enchimento capilar (TEC) é capaz de predizer pior desfecho clínico, pelo escalonamento ou não da antibioticoterapia.

Método: foi pesquisado o TEC em 50 pacientes neutropênicos febris no nadir de pós-quimioterapia, que deram entrada no departamento de emergência do Hospital Universitário de Brasília. Todos os incluídos estavam com uma pressão arterial média mínima de $75 \mathrm{mmHg}$, relação saturação de $\mathrm{O}_{2} / \mathrm{FiO}_{2}>300$ e escala de coma de Glasgow de 15. Os critérios de inclusão foram pelo menos três da síndrome da resposta inflamatória sistêmica (SRIS), suspeita de infecção e neutropenia pós-quimioterapia. O TEC foi calculado através da pressão sobre o indicador por 15 segundos e cronometrado o tempo de retorno à cor inicial. Foi estudado se há relação entre valor encontrado no TEC e escalonamento de antibiótico. O padrão-ouro utilizado para gravidade foi o nível de lactato. 
Resultados: trinta e um pacientes tiveram o TEC $\geq 3$ segundos, que se associou com o aumento da concentração de lactato ( $>2 \mathrm{mmol} / \mathrm{L} ; \mathrm{p}<0,05)$. Trinta e dois pacientes tiveram escalonados seus antibióticos, que se associou com o TEC $\geq 3$ segundos $(\mathrm{p}<0,01)$.

Conclusão: o TEC maior que três segundos mostrou-se eficaz para predizer escalonamento de antibiótico.

Palavras-chave: neutropenia, alterações na temperatura corporal, perfusão, febre.

\section{References}

1. de Naurois J, Novitzky-Basso I, Gill MJ, Marti FM, Cullen MH, Roila F; ESMO Guidelines Working Group. Management of febrile neutropenia: ESMO Clinical Practice Guidelines. Ann Oncol. 2010; 21 Suppl 5:v252-6.

2. Averbuch D, Orasch C, Cordonnier C, Livermore DM, Mikulska M, Viscoli C, et al. ; ECIL4, a joint venture of EBMT, EORTC, ICHS, ESGICH/ESCMID and ELN. European guidelines for empirical antibacterial therapy for febrile neutropenic patients in the era of growing resistance: summary of the 2011 4th European Conference on Infectious in Leukemia. Haematologica. 2013; 98(12):1826-35.

3. Steiner MJ, DeWalt DA, Byerley JS. Is this child dehydrated? JAMA. 2004; 291(22):2746-54

4. Pollard AJ, Nadel S, Ninis N, Faust SN, Levin M. Emergency management of meningococcal disease: eight years on. Arch Dis Child. 2007; 92(4):283-6.

5. Pamba A, Maitland K. Capillary refill: prognostic value in Kenyan children. Arch Dis Child. 2004; 89(10):950-5.

6. Kinnear EM. A clinical study of the relationship between capillary refill time and the transcutaneous partial pressure of oxygen. BSc Honours in Podiatry, at University College Northampton, March 1999.

7. Raimer PL, Han YY, Weber MS, Annich GM, Custer JR. A normal capillary refill time of $<2$ seconds is associated with superior vena cava oxygen saturations of $\geq 70 \%$. J Pediatr. 2011; 158(6):968-72.

8. Lima A, Jansen TC, van Bommel J, Ince C, Bakker J. The prognostic value of the subjective assessment of peripheral perfusion in critically ill patients. Crit Care Med. 2009; 37(3):934-8.

9. Makarov IV, Iarovenko GV. [Thermography in diagnosis and treatment efficacy evaluation of lower limbs arterial diseases]. Khirurgiia (Mosk). 2002; (9):31-6. 